\title{
EARLY-ONSET ACUTE TRANSVERSE MYELITIS FOLLOWING HEPATITIS B VACCINATION AND RESPIRATORY INFECTION
}

\section{Case report}

\author{
Luiz Fernando Fonseca ${ }^{1}$, Thelma Ribeiro Noce ${ }^{2}$, Maria Letícia Gambogi Teixeira ${ }^{2}$, \\ Antônio Lúcio Teixeira Jr³, Marco Aurélio Lana-Peixoto ${ }^{4}$
}

\begin{abstract}
Acute transverse myelitis is an acute inflammatory process of the spinal cord and it is a rare clinical syndrome in childhood. In this paper, we report a case of 3 years-old boy who developed acute onset tetraparesia following a viral respiratory infecction and hepatitis B vaccination. Magnetic resonance imaging of the spinal cord disclosed signal-intensity abnormalities from C4 to C3. A diagnosis of acute transverse myelitis was made and the patient was treated with IV methylprednisolone and IV immunoglobulin. The child had a fair outcome despite of the very acute course of the disease and the presence of a cervical sensory level which usually harbor a poor prognosis.
\end{abstract}

KEY WORDS: acute transverse myelitis, childhood, hepatitis B vaccination, respiratory infection.

\begin{abstract}
Mielite transversa aguda de início precoce precedida de vacinação para hepatite B e infecção viral respiratória: relato de caso.

RESUMO - A mielite transversa aguda é processo inflamatório agudo da medula espinhal de ocorrência rara na infância. Neste artigo, reportamos o caso de um menino de 3 anos que desenvolveu tetraparesia aguda precedida de infecção viral respiratória e pós-vacinação para Hepatite B. A imagem pela Ressonância Magnética da medula espinhal revelou anormalidade de aumento de sinal em C4-T3. Após o diagnóstico da mielite transversa aguda, o paciente foi tratado com metilprednisolona e imunoglobulina. Embora a doença tenha se apresentado de forma aguda e acompanhada de nível sensitivo, o que usualmente levaria a um prognóstico sombrio, a criança evoluiu favoravelmente,
\end{abstract}

PALAVRAS-CHAVE: mielite transversa aguda, infância, vacinação, hepatite $B$, infecção viral respiratória.

Acute transverse myelitis (ATM) is an acute inflammatory process of the spinal cord that can be classified in three distinct groups according to its etiology: myelitis due to a direct infection of the spinal cord; myelitis in the context of a systemic disease, such as leukemia or a connective tissue disorder; and myelitis with a suspected autoimmune basis'. The last group is the most common form of ATM and may occur as a post- or parainfectious condition ${ }^{2,3}$. Respiratory and intestinal infections are important potential triggers of ATM, but some postvaccinal cases have also been reported ${ }^{1}$. Direct infection of the spinal cord is a common cause of ATM in developing countries. In Brazil myelitis due schistosomiasis mansoni is well known although its prevalence in childhood remains to be determined ${ }^{4-6}$. ATM is a rare clinical condition in childhood and adolescence. In this group it mostly occurs in children over 5 years of age ${ }^{7}$. Although all functions of spinal cord may be disturbed, different degrees of disability occur. It

${ }^{1}$ Coordenador da Residência em Neurologia Infantil do Centro Geral de Pediatria (CGP), FHEMIG, Belo Horizonte MG, Brasil; ${ }^{2}$ Residente de Neurologia Infantil do CGP-FHEMIG; ${ }^{3}$ Residente de Neurologia do Hospital das Clínicas (HC) da Universidade Federal de Minas Gerais, Belo Horizonte MG, Brasil (UFMG); ${ }^{4}$ Professor Adjunto do Departamento de Neurologia da Faculdade de Medicina da UFMG e Coordenador do Centro de Investigação em Esclerose Múltipla (CIEM-Minas) do HC da UFMG.

Received 19 August 2002, received in final form 16 October 2002. Accepted 5 November 2002. 
has been observed that functional recovery depends much on the clinical presentation; an abrupt and severe onset usually pointing to a poorer prognosis ${ }^{1,8}$.

In this paper, we report a case of very early-onset ATM following a viral respiratory infection and hepatitis $B$ vaccination. We discuss the role of these events as trigger factors in the development of ATM.

\section{CASE}

A 3-year-old white boy was admitted to the Pediatric Intensive Care Unit for evaluation of an acute-onset flaccid tetraparesia. One day prior to his admission, he complained severe pain in his neck. Few hours later, he was already unable to stand or use his hands. The mental status had not changed and there was no report of headache or blurred vision. Ten days previously he had received the first dose of the hepatitis $B$ vaccine and presented mild upper airway respiratory symptoms such as rhinorrhea and cough but no fever. His previous medical history and family history were unremarkable. The child lived in Belo Horizonte with his

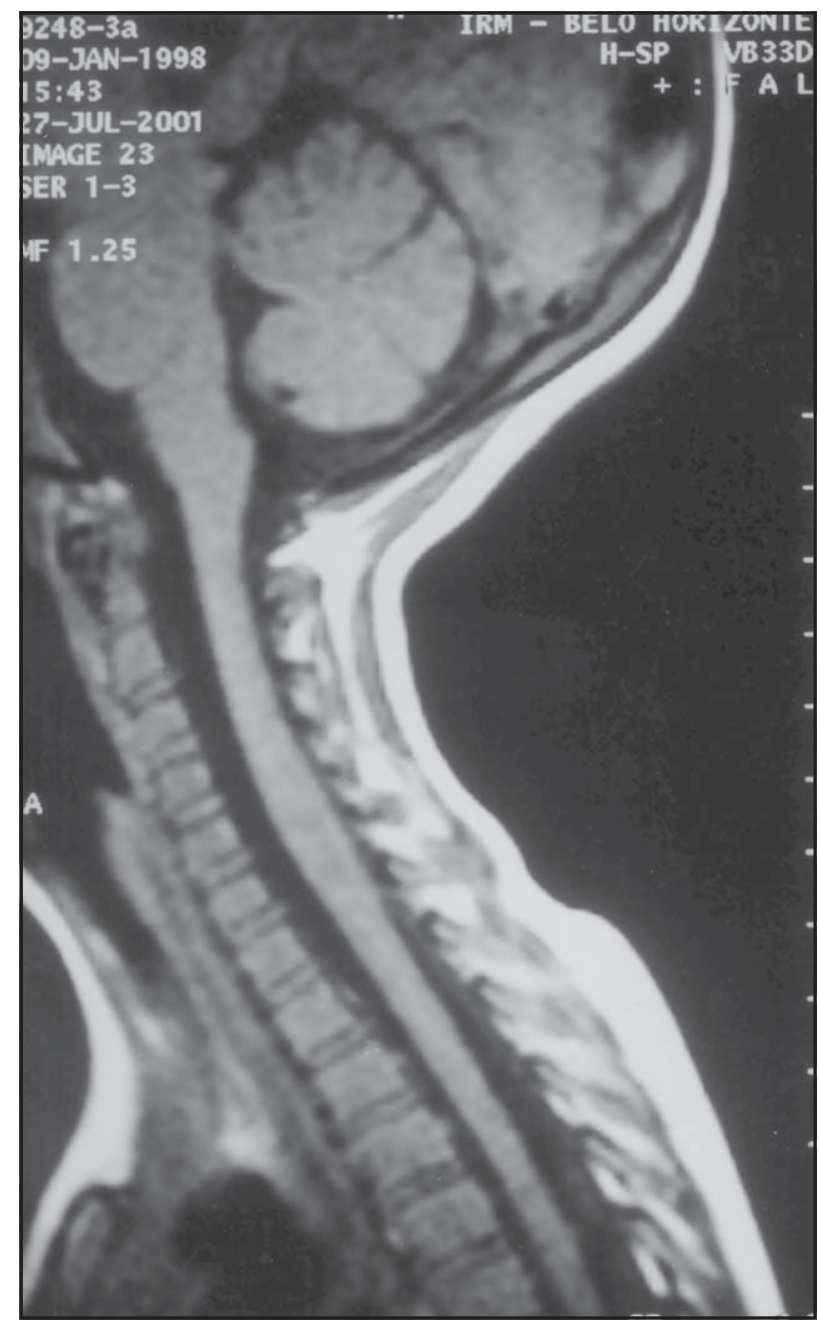

Fig 1. T1 weighed sagittal MR of the cervical spine exhibiting enlargement from C4 to T3. parents and a healthy 6-year-old brother. There was no contact of the children with natural water or domestic animals. At admission he presented urinary and intestinal retention and physical examination demonstrated an afebrile, eupneic child with a mean blood pressure of $64 \mathrm{mmHg}$ and a pulse rate of $132 \mathrm{rpm}$. No cognitive or cranial nerves disturbances were noted. He could not move any limb, the muscle tone was decreased, the deep tendon reflexes throughout absent and a sensory level was noticed at C5.

Laboratory work-up revealed a hematocrit of $28.6 \%$, white blood cell count of 9200 cells/mm3 (66\% neutrophils, $32 \%$ lymphocytes, $1 \%$ monocytes, $1 \%$ eosinophils), and normal platelet count. Coagulogram, ionogram, blood urea nitrogen and creatinine concentrations and C-reactive protein were all within normal range. Magnetic resonance imaging (MRI) of the spinal cord disclosed enlargement from C4 to T3 on T1-weighed images (Fig 1). On T2-weighed images, increased signal intensity was noticed over the same spinal segments (Fig 2). Cerebrospinal fluid (CSF) examination was unrevealing ( 2 WBCs, $100 \%$ ly; 8 RBCs; protein level of $25 \mathrm{mg} / \mathrm{dl}$ and glucose level of $82 \mathrm{mg} / \mathrm{dl}$ ).

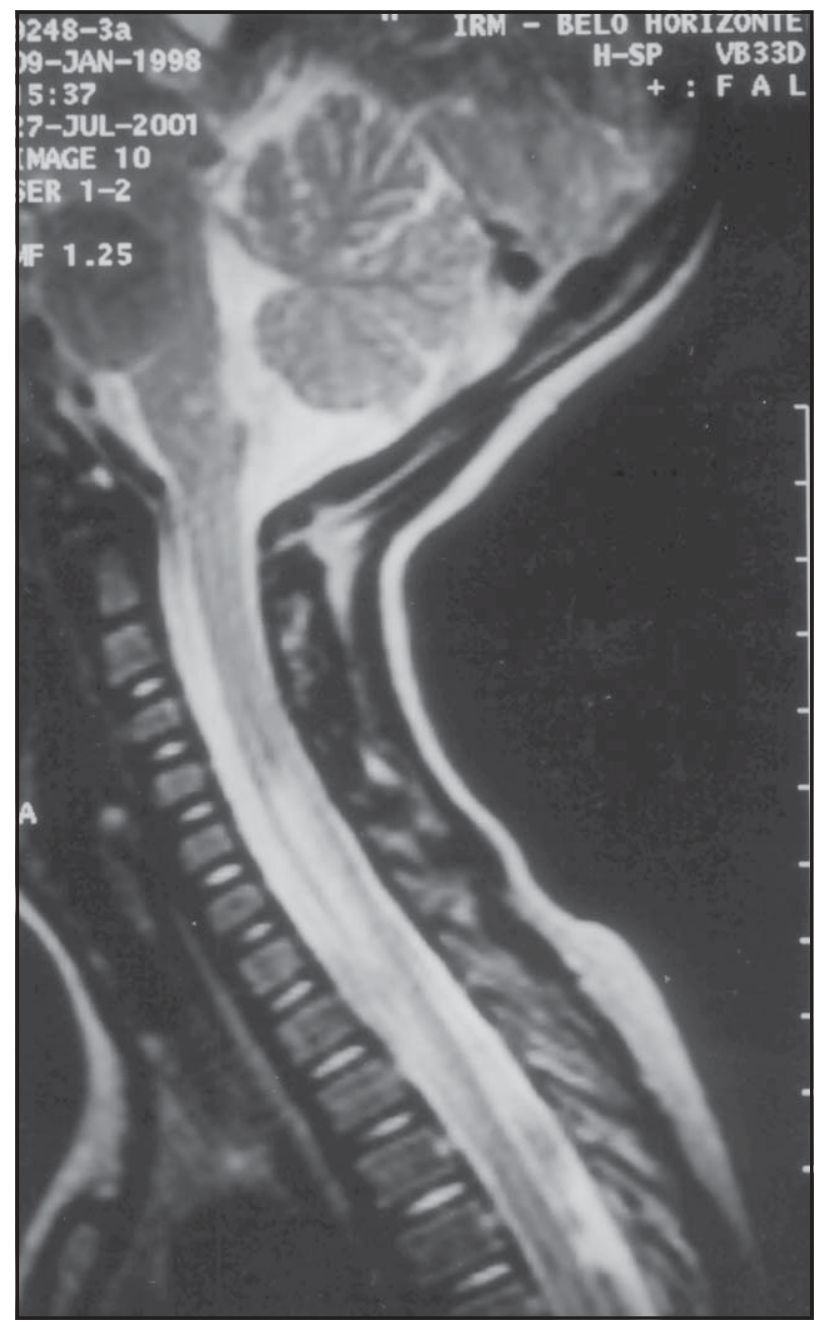

Fig 2. T2 weighed sagittal MR of the cervical spine exhibiting increased signal intensity over C4 to T3. 
A diagnosis of ATM was made and the patient was treated with IV methylprednisolone $(30 \mathrm{mg} / \mathrm{Kg} /$ day for five days) and IV immunoglobulin (400 mg/Kg/day for five days). He got better in the next six days with some voluntary movements in the limbs and recovery of the deep reflexes and was then transferred to the ward. Ten days later he presented low-grade fever, tachypnea and abdominal distension but no sign of neurological deterioration. Chest x-rays revealed consolidation in the inferior right hemithorax. The child was given oxacylline and gentamicine as treatment of nosocomial pneumonia but he developed respiratory insufficiency demanding mechanical ventilation. He was readmitted to the Intensive Care Unit and was put on vancomicine and cefepime with full respiratory recovery after 29 days of mechanical ventilatory support and tracheostomy. Follow-up at the Outpatient Clinics six months later showed that the child has mild bronchiectasis and atelectasias ascribed to the long period on mechanical ventilation but presents impressive neurological recovery, being able to walk with intermittent support and fully control his bladder and intestine functions. He has been on respiratory and motor rehabilitation programs.

\section{DISCUSSION}

The differential diagnosis of an acute disease of the spinal cord comprises a wide range of conditions ${ }^{1,7,8}$. Bacterial abscesses, spinal cord tumors, vascular malformations and haematomas can be usually ruled out by image methods. In the present case, MRI study failed to reveal any space-occupying condition, but the T2 signal abnormalities and spinal enlargement at levels related to clinical signs pointed to the diagnosis of ATM.

Transverse myelitis is a clinical syndrome which can be associated with a number of different conditions. It is, therefore, necessary to identify either a direct infection, a systemic disease or an autoimmune (post-infeccious or post-vaccinal) process ${ }^{9,10}$. Our patient had no evidence of a systemic disease (like lupus, leukemia), neither a history of contact with a potentially infective agent of the spinal cord (e.g. borreliosis, cat-scratch disease, toxocariasis, schistosomiasis). Similarly he had no clinical evidence of infections caused by viruses such as varicella-zoster virus, herpes simplex virus 1 and 2, Epstein-Barr virus, cytomegalovirus, coxsackievirus, echovirus, HIV which seldomly have been related to ATM.

It is probable that this child had post-infeccious or post-vaccinal ATM as the neurologic symptoms followed a viral respiratory infection and started ten days following hepatitis B immunization. An airway viral infection (adenovirus, respiratory syncytial virus, influenza) suggested by the mild respiratory symptoms presented by the patient also could be the index or trigger event. The mean interval from infection to the onset of neurological symptoms is reported to be between nine days to three weeks ${ }^{3}$. On the other hand the role played by hepatitis $B$ vaccine in this case cannot be overemphasized. Recent reports have linked hepatitis $B$ immunization to central nervous system demyelinating lesions ${ }^{11,12}$. It is noteworthy, however, that such cases reported in the literature consisted of acute disseminated encephalomyelitis (ADEM), an acute or subacute demyelinating disease of the neuraxis involving the brain and spinal cord with multifocal neurological deficits ${ }^{13-15}$. In the present case there was no evidence of brain involvement.

Multiple sclerosis (MS) is also an important differential diagnosis of ATM ${ }^{13-15}$. MS is an inflammatory demyelinating multifocal disease with a relapsing-remitting or a progressive course very rarely occurring under six years of age ${ }^{14-16}$. In addition to that MS lesions are usually less extensive and spinal cord enlargement is exceptional. On the contrary, in ATM demyelination spreads to multiple spinal segments and enlargement of the spinal cord is a common finding as in our patient.

Guillain-Barré syndrome could be also considered because of its high incidence and clinical similarities to ATM $^{17,18}$. As a matter of fact, some clinical features of the present case, such as flaccid tetraparesis and the possible involvement of respiratory muscles, might point to the diagnosis of Guillain-Barré syndrome rather than ATM. However, the albumin-cytologic dissociation in the CSF which remains as one of the most relevant feature of the disease was lacking. Additionally the MRI lesions were in favor of the diagnosis of ATM.

The clinical picture of ATM includes partial or complete paraplegia or quadriplegia, decrease or loss of deep reflexes, sensory impairment and varying degrees of bladder and bowel disturbance. Usually the full-blown disease is reached four weeks after onset, but in most cases the peak occurs in the first week with the level of involvement set at the onset ${ }^{2,3}$. In a few patients, however, the disease has an ascending course with risk of asphyxia when upper cervical segments (C3-C5) are involved. In the present case, the onset was sudden and the cervical spinal cord immediately involved. Notwithstandingly the child did not develop primary respiratory insufficiency and he has had a good neurological recovery.

Treatment of ATM is still a matter of controversy in the literature ${ }^{1,3}$. The efficacy of intravenous methylprednisolone in immune-mediated neurological 
disorders such as optic neuritis and MS, led some authors to use it in children with ATM $^{19,20}$. Recent studies have confirmed its efficacy shortening motor recovery and significantly increasing the proportion of patients able to walk independently at followup when compared to a historical control group ${ }^{19,20}$. Our patient's fair outcome in spite of the very acute course of the disease and the presence of a cervical sensory level, which usually harbor a poor prognosis, may be well ascribed to the early use of methylprednisolone $e^{1,2,8}$.

In spite of the history of both a viral respiratory infection and hepatitis $B$ immunization preceding the onset of ATM, the actual role played by each one in the development of this disease remains uncertain. It is possible that the concomitant exposition to two different antigens may increase the risk of an abnormal immune-mediated response in genetically susceptible individuals ${ }^{16}$.

\section{REFERENCES}

1. Knebusch M, Strassburg HM, Reiners K. Acute transverse myelitis in childhood: nine cases and review of the literature. Dev Med Child Neurol 1998;40:631-639.

2. Jeffery DR, Mandler RN, Davis LE. Transverse myelitis: retrospective analysis of 33 cases, with differentiation of cases associated with multiple sclerosis and parainfectious events. Arch Neurol 1993;50:532-535.

3. Victor M, Ropper AH. Diseases of the spinal cord. In Adams RD Victor M Principles of Neurology. 7.Ed. New York: McGraw Hill, 2001.
4. Ferrari TCA. Spinal cord schistosomiasis: a report of 2 cases and review emphasazing clinical aspects. Medicine 1999;78:176-190.

5. Nobre V, Silva LCS, Ribas JG, et al. Schistosomal myeloradiculopathy due to Schistosoma mansoni: report on 23 cases. Mem Inst Oswaldo Cruz 2001;96 (suppl):137-141.

6. Paz JA, Valente M, Casella EB, Marques-Dias MJ. Spinal cord schistosomiasis in children. Arq Neuropsiquiatr 2002;60:224-230.

7. Berman M, Feldman S, Alter M, et al. Acute transverse myelitis: incidence and etiologic considerations. Neurology 1981;31:966-971.

8. Dunne K, Hopkins IJ, Shield LK. Acute transverse myelopathy in childhood. Dev Med Child Neurol 1986;28:198-204.

9. Salgado CD, Weisse ME. Transverse myelitis associated with probable cat-scratch disease in a previously healthy pediatric patient. Clin Infect Dis 2000;31:609-611.

10. Yavuz H, Cakir M. Transverse myelopathy: an initial presentation of acute leukemia. Pediatr Neurol 2001;24:382-384.

11. Tourbah A, Gout O, Liblau R, et al. Encephalitis after hepatitis B vaccination: recurrent disseminated encephalitis or MS? Neurology 1999;53:396-401.

12. Touzé E, Gout O, Verdier-Taillefer MH et al. Premier épisode de démyélinisation du système nerveux central et vaccination contre l'hépatite B. Rev Neurol 2000;156:242-246.

13. Hartung HP, Grossman RI. ADEM: distinct disease or part of the MS spectrum? Neurology 2001;56:1257-1260.

14. Dale RC, De Sousa C, Chong WK, Cox TCS, Harding B, Neville BGR. Acute disseminated encephalomyelitis, multiphasic disseminated encephalomyelitis and multiple sclerosis in children. Brain 2000;123: 2407-2422.

15. Rust RS. Multiple sclerosis, acute disseminated encephalomyelitis, and related conditions. Semin Pediatric Neurol 2000;7:66-90.

16. Noseworthy JH, Lucchinetti C, Rodriguez M, Weinshenker BG. Multiple sclerosis. N Engl J Med 2000;343:938-952.

17. Fonseca LF, Horta MB, Gauzzi LDV. Polirradiculoneurite aguda (Síndrome de Guillain-Barré). In Fonseca LF, Pianetti G, Xavier CC (eds). Compêndio de Neurologia Infantil. Rio de Janeiro: Medsi, 2002.

18. Tellería-Díaz A, Calzada-Sierra DJ. Síndrome de Guillain-Barré. Rev Neurol 2002;34:966-976.

19. Lahat E, Pillar G, Ravid S, Barzilai A, Etzioni A, Shahar E. Rapid recorery from transverse myelopathy in children treated with methylprednisolone. Pediatr Neurol 1998;19:279-282.

20. Defresne P, Meyer L, Tardieu M, et al. Efficacy of high dose steroid therapy in children with severe acute transverse myelitis. J Neurol Neurosurg Psychiatry 2001;71:272-274. 